\title{
Heterogeneity and causation of organ dysfunction in Alström syndrome
}

\author{
R Paisey ${ }^{1 *}$, C Carey $^{1}$, R Seymour ${ }^{1}$, K Williams ${ }^{1}$, C Rockett ${ }^{1}$, K Vogler $^{1}$, S Bunce ${ }^{1}$, A White ${ }^{1}$, T Hiwot $^{2}$, R Cramb ${ }^{2}$, \\ M Waterson ${ }^{1}$
}

From First International Cilia in Development and Disease Scientific Conference (2012)

London, UK. 16-18 May 2012

\begin{abstract}
Alström syndrome (OMIM 203800) is an autosomal recessive condition caused by pathological mutations in the $A L M S 1$ gene of worldwide distribution prevalence. 200 subjects and longitudinal in depth studies of the UK cohort of 100 subjects have highlighted the extreme variation not only in the rate of visual and hearing loss but also in extent and progression of cardiac, renal, hepatic and endocrine dysfunction. The range in age at which visual acuity declines to $<6 / 36$ and/or when neuronal deafness is diagnosed is from 5 to 40 years. Life threatening cardiomyopathy occurs in $30 \%$ of neonates and can recur or arise de novo in $25 \%$ of all young adults from 12 to 25 years of age with sporadic cases later than this. Renal failure (CKD stage 5) occurs from 16 to 50 years in $25 \%$ of cases and hepatic cirrhosis in $10 \%$ between 10 and 40 years. Underlying this trend is some degree of cardiac and renal fibrosis and fatty liver in all, and severe insulin resistance. Progression from insulin resistance to type 2 diabetes and its severity and from fatty liver to fibrosis, then cirrhosis may be halted in early stages by lifestyle improvement especially in the second and third decades. Variation in deafness, renal and cardiac fibrosis differs within families but shows ethnic clustering suggestive that modifier genes contribute.
\end{abstract}

\section{Author details \\ ${ }^{1}$ South Devon Healthcare NHS Foundation Trust, UK. ${ }^{2}$ Queen Elizabeth \\ Medical Centre, Birmingham, UK.}

Published: 16 November 2012

'South Devon Healthcare NHS Foundation Trust, UK

Full list of author information is available at the end of the article
doi:10.1186/2046-2530-1-S1-P8

Cite this article as: Paisey et al.: Heterogeneity and causation of organ dysfunction in Alström syndrome. Cilia 2012 1(Suppl 1):P8.
Submit your next manuscript to BioMed Central and take full advantage of:

- Convenient online submission

- Thorough peer review

- No space constraints or color figure charges

- Immediate publication on acceptance

- Inclusion in PubMed, CAS, Scopus and Google Scholar

- Research which is freely available for redistribution

\section{Biomed Central}

C Biomed Central 